Article

\title{
Active Learning as a Beyond-the-Classroom Strategy to Improve University Students' Career Adaptability
}

\author{
Tracy Hui ${ }^{1}$ (D), Sam S. S. Lau ${ }^{2,3,4, *(\mathbb{D})}$ and Mantak Yuen ${ }^{5}$ \\ 1 Department of Management, Hong Kong Baptist University, Hong Kong, China; tracyhui@hkbu.edu.hk \\ 2 Careers and Employability Centre, School of Continuing Education, Hong Kong Baptist University, \\ Hong Kong, China \\ 3 College of International Education, School of Continuing Education, Hong Kong Baptist University, \\ Hong Kong, China \\ 4 Multidisciplinary Research Centre, School of Continuing Education, Hong Kong Baptist University, \\ Hong Kong, China \\ 5 Centre for Advancement in Inclusive and Special Education, Faculty of Education, \\ The University of Hong Kong, Pokfulam Road, Pokfulam, Hong Kong, China; mtyuen@hku.hk \\ * Correspondence: samlau@hkbu.edu.hk
}

check for

updates

Citation: Hui, T.; Lau, S.S.S.; Yuen,

M. Active Learning as a

Beyond-the-Classroom Strategy to

Improve University Students' Career

Adaptability. Sustainability 2021, 13,

6246. https://doi.org/10.3390/

su13116246

Academic Editors: Ana B. Bernardo, Adrian Castro-Lopez, Javier Puente and Leandro Almeida

Received: 30 April 2021

Accepted: 29 May 2021

Published: 1 June 2021

Publisher's Note: MDPI stays neutral with regard to jurisdictional claims in published maps and institutional affiliations.

Copyright: (c) 2021 by the authors. Licensee MDPI, Basel, Switzerland. This article is an open access article distributed under the terms and conditions of the Creative Commons Attribution (CC BY) license (https:// creativecommons.org/licenses/by/ $4.0 /)$.

\begin{abstract}
Geopolitical changes worldwide, together with rapid advances in technology, have created a situation where an individual's working life can present many new challenges. Helping students develop the attitudes and skills necessary to adapt to constant change along a career path has become a priority in education. Developing this career adaptability is becoming increasingly important to the sustainability of democracy, the economy, justice, human values, and equality. The authors of this paper argue that to improve the quality of our education system in universities, active learning should play a more important role to enrich the typical lecturing-learning processes. The aim of the study reported here was to examine the impact from implementing a 3-month active learning program that took university students beyond the classroom to increase their career adaptability and self-esteem and to strengthen their meaning in life. A mixed-method approach was adopted and conducted in two phases with 119 undergraduate students in human resources management at a university in Hong Kong. Findings suggested a significant improvement in career adaptability of the students after participating in the program when compared to a control group. However, data did not indicate any significant change in self-esteem and meaning in life in the training group. The findings support the valuable role of active learning as a strategy to enhance students' career adaptability in a changing but sustainable world of employment.
\end{abstract}

Keywords: active learning; career adaptability; Hong Kong; human resources management; university students; university teaching

\section{Introduction}

A review of the literature reveals that in this era of rapid technological and geopolitical change, career adaptability has become an increasingly important research topic in the field of career education [1]. It is also evident that, in the near future, our efforts to adjust to climate change will also affect employment opportunities by creating new jobs and making others redundant. If we are to sustain an acceptable quality of life, the ability of individuals to adapt to constant changes in employment has become a new essential 'life skill'. In addition to career adaptability, self-esteem and meaning in life are important to undergraduates' career and personal development. To our best knowledge, it remains unknown whether active learning contributes to these three outcomes.

\subsection{Career Adaptability}

Career Construction Theory defines career adaptability as the readiness to manage predictable and unpredictable career transitions, changes and challenges [2-4]. Career 
adaptability has been delineated into four self-regulatory strengths: concern, control, curiosity and confidence. Career Concern is the inner urge to plan for a career carefully and establish a career vision. Career Control represents a sense of responsibility and ownership to construct one's career and make career decisions. Career Curiosity refers to the exploration process to synthesize work-related information relative to personal strengths and interests. Career Confidence describes self-efficacy for managing vocational tasks, decisions and transitions $[2,5,6]$. For undergraduates, these four psychosocial competencies determine how successfully they deal with the school-to-work transition as well as their working life [7].

Career adaptability is an important part of life design [8] and is becoming a popular topic in vocational research and as a subject within career education courses. Two longitudinal studies have found that career courses boost the level of career adaptability of undergraduates in Hong Kong $[9,10]$, and cross-sectional studies suggest that attributes such as personality traits and self-esteem are antecedents of undergraduates' career adaptability [11-14].

\subsection{Self-Esteem}

If self-esteem is indeed an influence on older students' ability to acquire career adaptiveness, schools and universities could do more to build students' self-esteem. Self-esteem is reflected in personal beliefs about self-worthiness and value. A person possessing high self-esteem tends to feel accepted, respected and satisfied with who he or she is. That person recognizes, and is comfortable with, their personal strengths and weaknesses $[15,16]$

Kaveh, Hesampour, Ghahremani and Tabatabaee (2014) [17] found that one way to increase self-esteem of female secondary school students was to have the students engage in active peer-led education. They reported that students who participated in the activities had a significant increase in self-esteem. The research team explained that the increase in self-esteem appeared to stem from the collaboration and mutual support among peers. This type of collaborative learning process acts as a catalyst for behavioral change in terms of belongingness, attachment among peers, self-esteem, and purpose in life [18-20].

\subsection{Meaning and Purpose in Life}

Meaning in life is generally described as the feelings an individual has about the significance and purpose of their existence. People who believe their lives are high in meaning tend to develop valuable goals and feel fulfilled [21-23]. An instrument to assess an individual's meaning in life was developed by Steger and Frazier (2005) [23]. They conceived that 'meaning' may be found at two levels: the presence of meaning in life and search for meaning. The former connects to an already-acquired sense of how meaningful one's life is. The latter refers to the situation where one is still seeking meaning in one's life.

A study found that adolescents with purposeful work goals reported higher meaning in life and in schoolwork [24]. Hence, students who engaged in the program in this study to organize a teambuilding day for other HRM students might perceive their lives to be more purposeful.

\subsection{Active Learning}

In university classrooms, 'active learning' is being more widely adopted to enrich typical lecturing-learning processes and improve the quality of our education system. In contrast to the traditional lecturer-centered pedagogy commonly used in universities, active learning is a student-centered method in which students are engaged in the learning process and can benefit from the experiences [25]. Activity-based learning has long been the norm in early childhood education, and through the primary school years, but in universities it had been less common.

The belief that underpins student-centered learning is that it encourages students to become more autonomous by discovering and constructing their own knowledge and 
using their own initiative. The control is moved from teacher to the students to engage them in meaningful learning and to reflect upon their progress $[25,26]$.

Mounting evidence suggests that active learning surpasses traditional teaching methods in establishing knowledge and skill development [25,27-29]. However, the majority of studies of active learning have only explored its positive impact on teaching and learning effectiveness, so there is a paucity of information on the relationship between active learning and students' personal outcomes (such as career path and career readiness). There is a need to investigate how active learning can be adopted more widely as a strategy to improve older students' career adaptability and personal development [30]. It is hypothesized that a well-designed extracurricular activity-based learning program, implemented beyond the classroom, can be a sustainable approach that adds value to the formal curriculum. It is also hypothesized that the program may have a positive effect on participants' self-esteem, and may strengthen their purpose and meaning in life. An effective learning program should be able to enrich students' professional knowledge, and also strengthen their career resources.

\subsection{The Program}

The present study attempted to investigate whether an extracurricular activity with hands-on experiences in taking responsibility as a trainer of others could strengthen students' career adaptability, self-esteem and meaning in life.

The program was built on active learning principles, namely that (i) students learn best by doing, (ii) that activity promotes higher-order thinking, and (iii) that participation offers students practice opportunities that can aid their development [29,31,32]. The university students who participate in the extracurricular program would obtain hands-on experiences in taking responsibility for designing and delivering a team-building program.

The program also drew upon aspects of Career Construction Theory $[4,6]$ and connected three perspectives on vocational behavior-namely, developmental psychology, individual differences psychology, and narrative psychology [33]. Firstly, the developmental psychology perspective focuses on psychosocial adaptation and how individuals manage their own vocational development and difficulties. This 'career adaptability' attribute is the main variable considered in the present study. In particular, the intention was to compare the pre- and post-program changes that occurred for participants in the program (active learning group) and a control group of similar students who did not participate. It was anticipated that, by completion of the learning program, the students might have a clearer plan for pursuing their training and career development (career concern), a greater responsibility of constructing their future profession (career control), a higher curiosity to explore more information for their graduate job (career curiosity), and a higher efficacy to take up an entry-level training position (career confidence). Secondly, the individual difference perspective addresses the differences in vocational personality types and the different occupation interests that people may have [33]. With reference to this aspect, the study also helped to reveal whether the students' self-esteem would be strengthened after participating in the active learning program. Thirdly, the narrative psychology perspective examines the dynamic processes that individuals use to integrate their past life experiences, impose meaning on their present vocational behaviour, and gain inspiration for their future career. Such dynamics help explain why people fit work into their lives differently [33].

Three hypotheses were tested in the study:

Hypothesis 1. Compared to a control group, students who participate in an extracurricular active learning program will show higher career adaptability.

Hypothesis 2. Compared to a control group, students who participate in an extracurricular active learning program will show higher self-esteem.

Hypothesis 3. Compared to a control group, students who participate in an extracurricular active learning program will report a higher meaning in life. 


\section{Method}

\subsection{Design and Delivery of the Program}

The program was offered in two consecutive years to two cohorts of Year 3 Human Resources Management (HRM) undergraduates from a university in Hong Kong. The program took the form of an extracurricular activity with 13 half-day sessions held on 7 Saturdays/Sundays in the summer break (July and August). An invitation was made to the students for them to gain hands-on experience in designing and delivering an experiential team-building program. A professional trainer experienced in adventure programs was appointed as the coach. Under the guidance of the coach, students learned the fundamental adventure-based training concepts such as the value of working as a team, solving problems in a collaborative manner, supporting one another, the role of a facilitator. Students also learned the skills needed to design and deliver in-door experiential games by observing demonstrations by the coach and hands-on participation in some games. Students then spent a few sessions to brainstorm, discuss and refine the training plan for a one-day team-building workshop for which they would be responsible. On the last two half-days, students prepared team-building materials for a trial run.

The teambuilding workshop was to be part of the HRM program orientation held on the Saturday before the new academic year. Each year, around 100 HRM students from different cohorts, plus 15 graduates, usually participate in a team-building workshop as part of orientation for new students. On that day, students and graduates get together and participate in a series of indoor experiential activities and group games to foster relationships, cultivate a sense of group cohesion, and strengthen their team skills such as communication and team problem solving.

After the teambuilding workshop, the professional coach arranged a debriefing session for the student trainers to reflect on and consolidate their learning. The whole program lasted for around 3 months, covering initial training, teambuilding, workshop design to debriefing.

\subsection{Research Design and Procedures}

The study used a two-phase longitudinal design to compare the pre- and post-program changes between participants and the control group of classmates who did not participate. All participants were invited to complete an online questionnaire by email and WhatsApp on two occasions. Time 1 (pretest) was conducted before the first session of the program. At Time 2, all participants completed the questionnaire again approximately 3 months later. In addition to the quantitative data from the questionnaire, students of the second-year cohort were invited for a focus group interview in mid-November to collect qualitative responses on the active learning experience and its impact.

\subsection{Participants}

The participants in this program were full-time, third-year undergraduates from a Human Resource Management major at a university in Hong Kong. All participants in both training and control groups had completed a credit-bearing course with a fundamental understanding of training and development.

Human Resources Management (HRM) is one of the occupations that increasingly requires a relevant degree qualification $[34,35]$. In the training of HRM students, academic content and hands-on experiences are equally important to help students appreciate the purposes behind HRM functions and understand best practices [34]. In this respect, traditional pedagogies like lectures and written assignments are often inadequate to develop undergraduates as true professionals.

Previous studies have shown that an active learning approach appears to improve student learning and academic outcomes. For example, MacVaugh and Norton (2012) [36] identified the practical value of active learning in business education, and suggested that future research should investigate the connection between students' active learning experience and their later success on their career path. Similarly, North-Samardzic and De Witt (2019) [37] designed an online simulation program for HRM students to learn and 
apply theories and acquire conceptual knowledge. Their findings provide meaningful insights into how an online simulation can be an active learning tool that engages students in their learning.

In the first year of the study, 77 students completed the pre-training questionnaire and 57 students participated in the post-training questionnaire. In the second year, 75 students responded to the pre-training survey and 74 students participated in the post-training survey. All participants were invited to provide the last 4 digits of mobile phone number as an identifier. However, as shown in Table 1, only 51 pairs of pre- and post-survey responses were successfully identified by the 4-digit code in the first year in total and 68 pairs in the second year.

Table 1. Study participants in the training and control groups.

\begin{tabular}{cccc}
\hline Year & Training Participants & Control Group & Total \\
\hline First year & 20 & 31 & 51 \\
\hline Second year & 12 & 56 & 68 \\
\hline Total & 32 & 87 & 119 \\
\hline
\end{tabular}

Independent $t$-test was applied to validate the combination of the two samples from different years, and scores of Year 2017 samples $(\mathrm{N}=51)$ were compared to those of 2018 samples $(N=68)$ at each time point. There were no significant differences found between two samples for all measures at both pre- and post-training, so the two samples were combined for further analysis. The total sample included 119 students (59.7\% female), which consisted of 32 students in the training group and 87 classmates in the control group. The mean age was 21.28 years (range $=20-24 ; \mathrm{SD}=1.06$ ). Two sessions of follow-up focus group interviews were arranged. Ten students participated, 6 attended the first focus group session and 4 attended the second session.

\subsection{Measures}

As all participants were Chinese, the questionnaires were presented in the Chinese language, and the focus group discussions were conducted in Cantonese.

\subsubsection{Career Adaptability}

The Career Adapt-Abilities Scale-China Form [38] (CAAS-China) was used to measure career adaptability. The CAAS-China is a translation of the English form of the CAAS-International 2.0 [5]. The scale comprises 4 subscales: career concern, control, curiosity, and confidence. Each subscale contains 6 items rated on a 5-point Likert-type scale $(5=$ Strongest; $4=$ Very strong; $3=$ Strong; $2=$ Somewhat strong; and $1=$ Not strong). In the present study, Cronbach alphas were 0.94 (overall), 0.90 (Concern), 0.84 (Control), 0.82 (Curiosity) and 0.88 (Confidence) at Time 1.

\subsubsection{Self-Esteem}

The Chinese Rosenberg Self-Esteem Scale (CRSES) [39] was used to measure the global self-esteem of the participants. The CRSES is a translation of the English form of the Rosenberg Self-Esteem Scale (RSES) [16]. The scale consists of 5 positively worded items and 5 negatively worded items on a 4-point Likert-type scale ( $4=$ Strongly agree; $3=$ Agree; $2=$ Disagree; and $1=$ Strongly disagree). Cronbach alpha coefficient in this study was 0.86 before the training program.

\subsubsection{Meaning in Life}

The Meaning in Life Questionnaire [40] was used to assess the meaning in life of participants. The scale is divided into two subscales, with 5 items measuring the presence of meaning in life and 5 items measuring the search for meaning in life. All items are rated on a 7-point scale from 1 (absolutely untrue) to 7 (absolutely true). The reliability of the MLQ 
reported in this study was 0.77 at Time 1 and was 0.78 for the Presence subscale and 0.82 for the Search subscale.

For the focus group interview, an established in-depth interview approach with semistructured questions was adopted. The interview protocol consisted of three sections. Section One was a warm-up to invite interviewees to describe their overall experience in the program. In Section Two, students were invited to reflect on how their career adaptability, self-esteem and perceived meaning in life had changed as a result of the training experiences. Some prompts and probes were used during discussions to facilitate students to express their views in more detail. Section Three focused on identifying the most valuable gains, growth and challenges associated with this active learning experience.

\section{Results}

This study employed a mixed-methods approach, and the triangulation of data helped achieve more valid research findings. The results reported below indicate that the data collected through quantitative and qualitative methods led to similar findings.

\subsection{Pre- and Post-Program Surveys}

Table 2 presents means, standard deviations and internal consistency estimates for all variables at Time 1 and Time 2 . The correlation figures at pre- and post-training stages are also shown in Table 2 . All variables at Time 1 were found positively and significantly correlated to the score at Time 2 .

At Time 1, independent $t$-test found no significant differences between the training and control groups on all measures, indicating that the two samples could be regarded as reasonably matched before the program began.

To compare the scores on career adaptability, self-esteem and meaning in life for each group between Time 1 and Time 2, paired $t$-tests were conducted. For the training group, there was a significant change in career adaptability $(t(117)=2.449, p=0.016)$. In contrast, no significant change was found in self-esteem and meaning in life. For the control group, the paired $t$-test results showed no significant change for all scores from Time 1 to Time 2 . This result provided some indication that the changes in HRM students' scores could be due to the effects of the active learning program.

To test the hypotheses, a mixed design of ANOVA tests was conducted. Training participation (training and control) was input as a between-group factor, and time (pre and post-training) as a within-group factor. As illustrated in Table 3, the analysis revealed that there were significant differences at Time 1 and Time 2 between the training in overall career adaptability $(F(1,117)=4.03, p=0.047)$, career concern $(F(1,117)=6.46, p=0.012)$, and career confidence $(F(1,117)=4.96, p=0.028)$. Students who participated in the program showed higher career concern and career confidence, as compared to the control group. These results tend to support Hypothesis 1 . However, there was no significant change in the other career adaptability sub-scales (control, curiosity), nor was any change evident in self-esteem, or meaning in life and its two subscales, causing rejection of Hypotheses 2 and 3. 
Table 2. Means, Standard Deviations and Correlations among Variables.

\begin{tabular}{|c|c|c|c|c|c|c|c|c|c|c|c|c|c|c|c|}
\hline & & Time 1 & & & Time 2 & & & & & & & & & & \\
\hline Scale & Mean & Std. Deviation & $\alpha$ & Mean & Std. Deviation & $\alpha$ & 1 & 2 & 3 & 4 & 5 & 6 & 7 & 8 & 9 \\
\hline 1. Career adaptability & 3.31 & 0.65 & 0.94 & 3.37 & 0.69 & 0.95 & $0.56^{* * *}$ & $0.85^{* * *}$ & $0.90^{* * *}$ & $0.90^{* * *}$ & $0.91^{* * * *}$ & $0.48^{* * *}$ & $0.50^{* * *}$ & $0.43^{* * *}$ & $0.38^{* * *}$ \\
\hline 2. Career concern & 3.09 & 0.89 & 0.90 & 3.13 & 0.83 & 0.90 & $0.81^{* * *}$ & $0.52^{* * *}$ & $0.65^{* * *}$ & $0.66^{* * *}$ & $0.67^{* * *}$ & $0.44^{* * *}$ & $0.47^{* * *}$ & $0.41^{* * *}$ & $0.36^{* * *}$ \\
\hline 3. Career control & 3.47 & 0.75 & 0.84 & 3.46 & 0.80 & 0.86 & $0.87^{* * *}$ & $0.56^{* * *}$ & $0.53^{* *}$ & $0.78^{* * *}$ & $0.78^{* * *}$ & $0.49^{* * *}$ & $0.43^{* * *}$ & $0.38^{* * *}$ & $0.32^{* * *}$ \\
\hline 4. Career curiosity & 3.38 & 0.71 & 0.82 & 3.45 & 0.70 & 0.85 & $0.85^{* * *}$ & $0.53^{* * *}$ & $0.68^{* * *}$ & $0.47^{* * *}$ & $0.80^{* * *}$ & $0.29^{* *}$ & $0.42^{* * *}$ & $0.33^{* * *}$ & $0.36^{* * *}$ \\
\hline 5. Career confidence & 3.33 & 0.72 & 0.88 & 3.44 & 0.78 & 0.89 & $0.88^{* * *}$ & $0.57^{* * *}$ & $0.75^{* * *}$ & $0.71^{* * * *}$ & $0.44^{* * *}$ & $0.46^{* * *}$ & $0.44^{* * *}$ & $0.38^{* * *}$ & $0.33^{* * *}$ \\
\hline 6. Self-esteem & 2.79 & 0.44 & 0.86 & 2.79 & 0.43 & 0.86 & $0.34^{* * *}$ & $0.28^{* *}$ & $0.42^{* * *}$ & 00.1 & $0.32^{* * *}$ & $0.70^{* * *}$ & $0.51^{* * *}$ & $0.57^{* * *}$ & $0.23^{*}$ \\
\hline 7. Meaning in life & 5.10 & 0.66 & 0.77 & 5.18 & 0.71 & 0.83 & $0.41^{* * *}$ & $0.36^{* * *}$ & $0.33^{* * *}$ & $0.34^{* * *}$ & $0.36^{* * *}$ & $0.46^{* * *}$ & $0.66^{* * *}$ & $0.86^{* * *}$ & $0.77^{* * *}$ \\
\hline $\begin{array}{l}\text { 9. Meaning in } \\
\text { life-Search }\end{array}$ & 5.39 & 0.80 & 0.82 & 5.43 & 0.76 & 0.83 & $0.27^{* *}$ & 0.19 * & 00.13 & $0.36^{* * *}$ & $0.25^{* *}$ & 00.06 & $0.72 * * *$ & 00.16 & $0.59 * * *$ \\
\hline
\end{tabular}

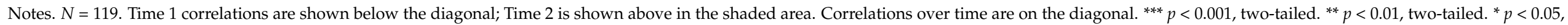
two-tailed. 
Table 3. Means and Standard Deviations of Training and Control Groups and Results of Mixed Design of ANOVAs.

\begin{tabular}{|c|c|c|c|c|c|}
\hline \multirow[b]{2}{*}{ Measures } & \multicolumn{2}{|c|}{ Training Group } & \multicolumn{2}{|c|}{ Control Group } & \multirow{2}{*}{$\begin{array}{c}\text { Mixed } \\
\text { ANOVAs F }\end{array}$} \\
\hline & $\begin{array}{c}\text { Pre-Test } \\
\text { Mean }\end{array}$ & $\begin{array}{l}\text { Post-Test } \\
\text { Mean }\end{array}$ & $\begin{array}{c}\text { Pre-Test } \\
\text { Mean }\end{array}$ & $\begin{array}{l}\text { Post-Test } \\
\text { Mean }\end{array}$ & \\
\hline Career adaptability & 3.38 & 3.62 & 3.29 & 3.28 & $4.03 *$ \\
\hline Career concern & 3.21 & 3.44 & 3.04 & 3.02 & $6.46^{*}$ \\
\hline Career control & 3.53 & 3.69 & 3.44 & 3.37 & 2.16 \\
\hline Career curiosity & 3.48 & 3.70 & 3.34 & 3.36 & 1.76 \\
\hline Career confidence & 3.28 & 3.66 & 3.35 & 3.37 & $4.96^{*}$ \\
\hline Self-esteem & 2.79 & 2.84 & 2.79 & 2.77 & 1.50 \\
\hline Meaning in life & 5.31 & 5.37 & 5.03 & 5.12 & 0.06 \\
\hline Meaning in life-Presence & 4.86 & 5.13 & 4.79 & 4.88 & 1.14 \\
\hline Meaning in life-Search & 5.75 & 5.61 & 5.26 & 5.36 & 2.56 \\
\hline
\end{tabular}

Note. $N=32$ for training group; $N=87$ for control group. Only cases that provide both pretest and posttest responses are included here. Mixed ANOVA $=$ mixed analysis of variance. ${ }^{* * *} p<0.001,{ }^{* *} p<0.01 .{ }^{*} p<0.05$.

\subsection{Focus Groups}

The qualitative responses recorded through the interviews were studied by applying content analysis [41]. Main themes and categories emerging from the responses were referred to the respective categories in the survey instrument. For example, in the Career Adapt-Abilities Scale (CAAS) [5], a person who exhibits greater 'career concern' is "thinking about what his/her future will be like", and "planning how to achieve future goals". Important statements from the students were then matched to attributes in CAAS. The same procedure was used to evaluate comments linked to career control, curiosity, and confidence. The responses obtained from the focus group interviews are reported below under: (1) overall learning experience; (2) career adaptability; (3) self-esteem; and (4) meaning in life.

Overall learning experience. The interviewees consistently agreed that the extracurricular active learning program was a valuable experience. Students described it as a "successful" and "valuable" (even "indescribable") experience that "satisfied" their needs. A student commented that,

"Our classmates who haven't joined [the program] missed a precious learning opportunity that they couldn't obtain again."

Career adaptability. The collaboration and hands-on involvement in the planning and executing of a team-building workshop had strengthened students' adaptability competencies. Some of these competencies equate with specific items in the Career Adapt-Abilities Scale (CAAS) [5]. These specific items appear in italics in the material below.

For example, two sub-themes related to career concern are identified. First, some students "become aware of the career choices". One student said,

"Among various HRM functions, I like training and development more, but I was not sure whether it would be my career direction. This program makes my career interest certain, and I find I am capable of handling the duties of a trainer."

Another student touched on their "plan to achieve career goals", saying that: "I will take a training and development related internship before graduation in order to prepare for my future career."

Career control. A few responses collected in the interviews subtly displayed career control characteristics. Two students shared that they learned to become more proactive and happier, which was similar to "keeping upbeat". Two students also showed the characteristic of "sticking up for my beliefs". One said: "No matter the future job is, and whether I like or dislike it, this [trainer] experience made me realize that a positive attitude is the most important. Every attempt can be beneficial to my future."

Career curiosity. All students expressed a view that the active learning program provided "opportunities to grow as a person". They not only learned some training skills and knowledge, they also found teamwork, collaboration and leadership capabilities 
were enhanced. Two students shared that their reason for enrolling in this program was to try something new, this equates with "curious about new opportunities" in the Career Adapt-abilities Scale.

Career confidence. All six characteristics of career confidence were evident in the focus group conversations. The fact that they achieved the teambuilding day built their confidence by proving that they were able to "perform tasks efficiently". The students were highly responsible and showed that they can "take care to do things well". For example, a student shared: "It is essential to get well prepared and think about how to explain the game rules clearly so that participants find the game easy to understand and attractive." Another opined: "As I have committed to this program, I know I have to be responsible and complete all of the tasks properly."

Moreover, all of the students reported that "learning new skills" was the most valuable takeaway. For instance, a student shared: "I have learned many new skills such as how to lead a team, design team-building activities, debriefing skills and so on."

Indeed, being in charge of team-building day for a hundred participants was a great mission for the students. Throughout the process, they stretched themselves to achieve this mission. A student provided feedback which showed the characteristic of "working up to my ability". He said: "I discovered that training and development is not easy. For instance, trainers are responsible for uncovering people's talents. On the team building day, I tried to facilitate the participants to use their unique abilities in different games bit by bit. But I know I need to sharpen my [facilitation] skills further."

Last but not least, students had demonstrated the confidence and strength to "overcoming obstacles" and "solve problems". Some unpredictable happenings occurred before or on the day of team building, but with good teamwork they coped with these. Several students also shared that being a trainer was the very first huge challenge in life. Positive self-talk helped them come out of their comfort zone and enabled them to speak in front of the people and take up the facilitator role. A few students also reminded themselves, "I'm capable!", "Be brave!" and "Just do it!".

Self-esteem. Although statistical testing did not reveal significant increases in selfesteem, most of the students reported that they became more confident and optimistic. An interviewee explained: "At that moment on team building day, my self-esteem was high; but after a while, when faced with challenges, I fell back into a person with low self-esteem. I think personal growth takes time. A single exposure can't really build self-esteem."

Meaning in life. Again, statistical testing did not provide evidence of increased meaning in life. However, a few students did find that this 3-month program was a meaningful experience that gave them purpose. A student shared: "Before that time, study was the only thing in my life; but this learning experience has widened my horizon and enriched my life. I have learned a lot of new skills which are practical and beyond textbooks. I can use these skills in my future career."

Similarly, another student added: "The most meaningful thing is that I can contribute to the HRM degree program. The team building day fostered the bonding among HRM students of different cohorts."

These two responses somewhat reflect "presence of meaning"-but the sense of purpose and fulfilment was confined to the team building event and did not affect students' life as a whole.

One student briefly touched upon "search for meaning", and said: "Everyone pursues meaning in life. I didn't want to be a leader before. In this program I have come out of my comfort zone to be a leader this time. When challenges come in future, this learning experience would remind me how meaningful it is to try, regardless of success or failure."

\section{Discussion}

The extracurricular active learning program in this study was designed as part of an initiative for university students that takes learning beyond the classroom. The implications of the study are organized according to four key findings. 
First, the HRM students who participated in the study reported a strengthening of three aspects of career adaptability (overall adaptability, career concern and career confidence), whereas no significant change was found among their classmates in the control group. This finding partially supports Hypothesis 1 and is in line with active learning and career construction principles. From the active learning perspective, the program provided a safe collaborative setting for students to plan and implement the team-building day. This undertaking was a work-like mission with a real purpose. The firsthand experience obtained in the program is in many ways a realistic job [42] where students had a taste of the training profession. The students built their work culture and were involved in decision making. As the process evolved, this peer learning community illustrated how active learning effectively helps higher education students' profession development [29].

Second, from the career construction perspective, the student group provided a showcase of how they had to transform themselves to become trainers to lead a one-day teambuilding workshop. To complete this mission, they had to handle a series of tasks and to face many known and unknown challenges. Such transition demanded a high level of adaptability that required students to push beyond their current level to reach a higher capability. Savickas (2005) [33] opined that adaptation is fostered through five stages: orientation, exploration, establishment, management, and disengagement. The students in this study progressed through these five stages. They began the trainer role as an orientation period in which they become aware of the need for acquiring new skills. To adapt to the new role, students explored the domain by seeking information about the functions of a trainer. Then, students gradually established themselves in the new trainer role and learned to manage all new challenges one by one. Finally, they disengaged from the trainer role upon completion of the 3-month program. From the students' responses in the interviews, the experience of being a training facilitator to organize and lead a team on the team-building day greatly enhanced their career concern and confidence attributes. They became more aware of whether training and development is a profession for them to pursue upon graduation.

Third, all participating students found the learning experience valuable, and the changes in their adaptability supports a view that occupation-oriented active learning programs of this type could supplement other university courses to enrich undergraduates' capabilities. The evidence that active learning boosted students' overall career adaptability appears to be a way to prepare graduating students to enter and sustain today's employment market. From West to East, many employers comment that the new generation of graduates are not ready for real-life work situations. For example, Forbes reported that only $13 \%$ of adults strongly agreed that college graduates in the US are well-prepared to work [43]. An experiential learning experience such as the program here may serve to narrow the gap between learning at the university and starting a career. In particular, programs such as this could enhance undergraduates' career adaptability required in today's constantly changing world of work $[3,44]$.

Fourth, self-esteem improvement and change in the meaning of life were not produced by this program, possibly because the program was of relatively short duration. Although the students revealed in discussions that they appreciated the program and found themselves with higher self-confidence, the experience did not produce long-lasting change in their feeling of self-worth and meaning in life. The nature of the tasks within the program did not really provide experiences that could have a deep effect on the students' perceived meaning in life. Future versions of the program could endeavor to provide experiences that might address these attributes more directly [45].

\section{Limitations}

The interpretive scope of the results is limited by the small sample size, and the 3-month longitudinal nature of the data from a sample of students in one program of a university. Future research should involve a larger number of matched pre- and post- 
survey participants in an active training program in other settings and of longer duration. In addition, the present study found that the program did not significantly change students' self-esteem and meaning in life. Yet, in the interview the students did report positive experiences. Future research could confine the scope to evaluate the impact on specific outcomes such as career self-efficacy or meaningfulness of learning. Furthermore, some students said that their positive self-talk helped them overcome challenges encountered in the active learning project. Future research could extend the study and test whether positive self-talk is also relevant to the enhancement of career adaptability.

\section{Conclusions}

The study added to the active learning and career adaptability literature in higher education by collecting data using a mixed (quantitative and qualitative) and experimental approach. The findings provide some initial evidence of the potential value of a university active learning program that places students in leadership roles beyond the classroom. It appears that such a program is an example of education which contributes to students sustainable career planning confidence and adaptability. The results suggest that situations that simulate real-life working conditions and present real-life challenges could add value to undergraduates' career preparation.

Author Contributions: Conceptualization, T.H.; methodology, T.H. and S.S.S.L.; data collection and curation, T.H. and S.S.S.L.; writing-original draft preparation, T.H.; writing-review and editing, S.S.S.L., T.H. and M.Y.; All authors have read and agreed to the published version of the manuscript.

Funding: The APC was funded by Department of Management, Hong Kong Baptist University.

Institutional Review Board Statement: The study was approved by the Research Ethics Committee of Hong Kong Baptist University.

Informed Consent Statement: Informed consent was obtained from all subjects involved in the study.

Data Availability Statement: Data are available from the corresponding author upon reasonable request.

Acknowledgments: The authors would like to express their appreciation to Mandy Mao and Albert $\mathrm{Ng}$ for their technical assistance. Appreciation also goes to the student participants. Valuable comments from the anonymous reviewers were appreciated.

Conflicts of Interest: The authors declare no conflict of interest.

\section{References}

1. Chen, H.; Fang, T.; Liu, F.; Pang, L.; Wen, Y.; Chen, S.; Gu, X. Career Adaptability Research: A Literature Review with Scientific Knowledge Mapping in Web of Science. Int. J. Environ. Res. Public Health 2020, 17, 5986. [CrossRef]

2. Savickas, M.L. The theory and practice of career construction. Career Dev. Couns. Putt. Theory Res. Work 2005, 1, 42-70.

3. Savickas, M.L. New Questions for Vocational Psychology: Premises, Paradigms, and Practices. J. Career Assess. 2011, 19, 251-258. [CrossRef]

4. Santilli, S. The theory and practice of career construction. Career Couns. 2016, 1, 192-202. [CrossRef]

5. Porfeli, E.J.; Savickas, M.L. Career Adapt-Abilities Scale-USA Form: Psychometric properties and relation to vocational identity. J. Vocat. Behav. 2012, 80, 748-753. [CrossRef]

6. Savickas, M.L. Career Adaptability: An Integrative Construct for Life-Span, Life-Space Theory. Career Dev. Q. 1997, 45, 247-259. [CrossRef]

7. Savickas, M.L. The theory and practice of career construction. In Career Counselling; Lent, R.W., Brown, S.D., Eds.; John Wiley \& Sons: Hoboken, NJ, USA, 2020; pp. 192-202.

8. Zhou, M.; Lin, W. Adaptability and Life Satisfaction: The Moderating Role of Social Support. Front. Psychol. 2016, 7, 1134. [CrossRef]

9. Cheung, R.; Jin, Q. Impact of a Career Exploration Course on Career Decision Making, Adaptability, and Relational Support in Hong Kong. J. Career Assess. 2015, 24, 481-496. [CrossRef]

10. Lau, S.; Wan, K.; Tsui, M. Evaluation of a Blended Career Education Course during the COVID-19 Pandemic on Students' Career Awareness. Sustainability 2021, 13, 3471. [CrossRef]

11. Hui, T.; Yuen, M.; Chen, G. Career Adaptability, Self-Esteem, and Social Support Among Hong Kong University Students. Career Dev. Q. 2018, 66, 94-106. [CrossRef] 
12. Hui, T.; Yuen, M.; Chen, G. Career-Related Filial Piety and Career Adaptability in Hong Kong University Students. Career Dev. Q. 2018, 66, 358-370. [CrossRef]

13. Rudolph, C.W.; Lavigne, K.; Zacher, H. Career adaptability: A meta-analysis of relationships with measures of adaptivity, adapting responses, and adaptation results. J. Vocat. Behav. 2017, 98, 17-34. [CrossRef]

14. Storme, M.; Celik, P.; Myszkowski, N. A forgotten antecedent of career adaptability: A study on the predictive role of withinperson variability in personality. Pers. Individ. Differ. 2020, 160, 109936. [CrossRef]

15. Coopersmith, S. The Antecedents of Self-Esteem; W. H. Freeman \& Co.: San Francisco, CA, USA, 1967; Volume 34, p. 283. [CrossRef]

16. Avison, W.R.; Rosenberg, M. Conceiving the Self. Can. J. Sociol. Cah. Can. Sociol. 1981, 6, 212. [CrossRef]

17. Kaveh, M.H.; Hesampour, M.; Ghahremani, L.; Tabatabaee, H.R. The effects of a peer-led training program on female students' self-esteem in public secondary schools in Shiraz. J. Adv. Med Educ. Prof. 2014, 2, 63-70.

18. Gorrese, A.; Ruggieri, R. Peer attachment and self-esteem: A meta-analytic review. Pers. Individ. Differ. 2013, 55, 559-568. [CrossRef]

19. Malak, A.T.; Bektash, M.; Turgay, A.S.; Tuna, A.; Genç, R.E. Effects of peer education, social support and self esteem on breast self examination performance and knowledge level. Asian Pac. J. Cancer Prev. 2009, 10, 605-608.

20. Adamchak, S.E. Youth Peer Education in Reproductive Health and HIV/AIDS: Progress, Process and Programming for the future. Youth Issues Paper 7. Family Health International, Youth Net Program. 2006. Available online: https://www.yumpu.com/en/ document/read/46030012/youth-peer-education-in-reproductive-health-and-hiv-aids (accessed on 22 May 2021).

21. Crumbaugh, J.C.; Maholick, L.T. An experimental study in existentialism: The psychometric approach to Frankl's concept of noogenic neurosis. J. Clin. Psychol. 1964, 20, 200-207. [CrossRef]

22. Ho, M.Y.; Cheung, F.M.; Cheung, S.F. The role of meaning in life and optimism in promoting well-being. Pers. Individ. Differ. 2010, 48, 658-663. [CrossRef]

23. Steger, M.F.; Frazier, P. Meaning in Life: One Link in the Chain from Religiousness to Well-Being. J. Couns. Psychol. 2005, 52, 574-582. [CrossRef]

24. Yeager, D.S.; Bundick, M.J. The Role of Purposeful Work Goals in Promoting Meaning in Life and in Schoolwork during Adolescence. J. Adolesc. Res. 2009, 24, 423-452. [CrossRef]

25. Bonwell, C.C.; Eison, J.A. Active Learning: Creating Excitement in the Classroom. In 1991 ASHE-ERIC Higher Education Reports; ERIC: Washington, DC, USA, 1991.

26. Barr, R.B.; Tagg, J. From Teaching to Learning-A New Paradigm for Undergraduate Education. Chang. Mag. High. Learn. 1995, 27, 12-26. [CrossRef]

27. Prince, M. Does Active Learning Work? A Review of the Research. J. Eng. Educ. 2004, 93, 223-231. [CrossRef]

28. Chi, M.T.H.; Wylie, R. The ICAP Framework: Linking Cognitive Engagement to Active Learning Outcomes. Educ. Psychol. 2014, 49, 219-243. [CrossRef]

29. Dewing, J. Moments of movement: Active Learning and practice development. Nurse Educ. Pr. 2010, 10, 22-26. [CrossRef]

30. Chan, Y.-K. Investigating the relationship among extracurricular activities, learning approach and academic outcomes: A case study. Act. Learn. High. Educ. 2016, 17, 223-233. [CrossRef]

31. Dewing, J. Becoming and Being Active Learners and Creating Active Learning Workplaces: The Value of Active Learning in Practice Development. Int. Pract. Dev. Nurs. Healthc. 2009, 273-294. [CrossRef]

32. Meyers, C.; Jones, T.B. Promoting Active Learning. Strategies for the College Classroom; ERIC: Washington, DC, USA, $1993 ;$ p. 192.

33. Savickas, M.L. Career construction theory. Encycl. Career Dev. 2005, 1, 84-88.

34. Hallier, J.; Summers, J. Dilemmas and outcomes of professional identity construction among students of human resource management. Hum. Resour. Manag. J. 2011, 21, 204-219. [CrossRef]

35. Mason, G. High Skills Utilisation under Mass Higher Education: Graduate employment in service industries in Britain. J. Educ. Work. 2002, 15, 427-456. [CrossRef]

36. MacVaugh, J.; Norton, M. Introducing sustainability into business education contexts using active learning. Int. J. Sustain. High. Educ. 2012, 13, 72-87. [CrossRef]

37. North-Samardzic, A.; De Witt, M. Designing a Human Resource Management Simulation to Engage Students. J. Manag. Educ. 2019, 43, 359-395. [CrossRef]

38. Hou, Z.-J.; Leung, S.A.; Li, X.; Li, X.; Xu, H. Career Adapt-Abilities Scale-China Form: Construction and initial validation. J. Vocat. Behav. 2012, 80, 686-691. [CrossRef]

39. Leung, A.N.-M.; Wong, S.S.-F.; Wong, I.W.-Y.; McBride-Chang, C. Filial Piety and Psychosocial Adjustment in Hong Kong Chinese Early Adolescents. J. Early Adolesc. 2009, 30, 651-667. [CrossRef]

40. Steger, M.; Frazier, P.; Oishi, S.; Kaler, M. The meaning in life questionnaire: Assessing the presence of and search for meaning in life. J. Couns. Psychol. 2006, 53, 80-93. [CrossRef]

41. Wilkinson, D.; Birmingham, P. Using Research Instruments: A Guide for Researchers; Psychology Press: Hove, UK, 2003 ; p. 192.

42. Dugoni, B.L.; Ilgen, D.R. Realistic job previews and the adjustment of new employees. Acad. Manag. J. 1981, $24,579-591$.

43. Busteed, B. Why Aren't Graduates Ready for Work? They're The Least Working Generation in U.S. History. Forbes, 29 March 2019. Available online: https://www.forbes.com/sites/brandonbusteed/2019/03/29/why-arent-graduates-ready-for-work-theyrethe-least-working-generation-in-us-history/?sh=532baf475e58 (accessed on 22 May 2021). 
44. Savickas, M.L.; Nota, L.; Rossier, J.; Dauwalder, J.-P.; Duarte, M.E.; Guichard, J.; Soresi, S.; Van Esbroeck, R.; van Vianen, A.E. Life designing: A paradigm for career construction in the 21st century. J. Vocat. Behav. 2009, 75, 239-250. [CrossRef]

45. Yuen, M.; Chung, Y.B.; Lee, Q.A.Y.; Lau, P.S.Y.; Chan, R.M.C.; Gysbers, N.C.; Shea, P.M.K. Meaning in life and school guidance programs: Adolescents' voices from Hong Kong. Int. J. Educ. Vocat. Guid. 2020, 20, 653-676. [CrossRef] 